\title{
Comparison of the effects of human recombinant insulin-like growth factor I and insulin on plasma amino acid concentrations and leucine kinetics in humans
}

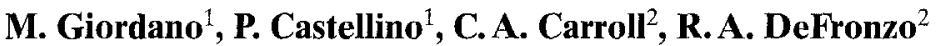 \\ ${ }^{1}$ Institute of Internal Medicine and Nephrology, Second University of Naples, Naples, Italy \\ ${ }^{2}$ Department of Medicine, Division of Diabetes, University of Texas Health Science Center at San Antonio, \\ and The Audie L. Murphy Veteran's Memorial Hospital, San Antonio, Texas, USA
}

Summary We examined the effects of recombinant human insulin-like growth factor I (IGF-I) and insulin on the plasma amino acid (AA) profile and leucine kinetics in eight normal subjects. IGF-I was infused at $52 \mathrm{pmol} \cdot \mathrm{kg}^{-1} \cdot \mathrm{min}^{-1}$, in combination with prime-continuous $\left[1-{ }^{14} \mathrm{C}\right]$ leucine infusion, to obtain steady-state plasma concentrations of total $(54 \pm 3$ $\mathrm{nmol} / 1)$ and free (7.3 $\pm 1 \mathrm{nmol} / \mathrm{l})$ IGF-I (study 1$)$. In response to IGF-I, plasma AA levels declined by $37 \pm 3 \%(1975 \pm 198$ to $1368 \pm 120 \mu \mathrm{mol} / \mathrm{l})$ and total branched chain amino acids (BCAA) declined by $34 \pm 3 \%(390 \pm 21$ to $256 \pm 13 \mu \mathrm{mol} / 1)$. This hypoaminoacidaemic effect was associated with a decline in endogenous leucine flux of $17 \pm 2 \%(1.88 \pm 0.05$ to $\left.1.57 \pm 0.04 \mu \mathrm{mol} \cdot \mathrm{kg}^{-1} \cdot \mathrm{min}^{-1}\right)$ and leucine oxidation of $17 \pm 1 \%(0.31 \pm 0.02$ vs $0.26 \pm 0.02 \mu \mathrm{mol}$. $\mathrm{kg}^{-1} \cdot \mathrm{min}^{-1}$ ) (both $p<0.01 \mathrm{vs}$ basal). The same subjects underwent a second study (study 2 ) in which insulin was infused at $6.22 \mathrm{pmol} \cdot \mathrm{kg}^{-1} \cdot \mathrm{min}^{-1}$ to obtain a steady-state plasma insulin concentration of $530 \pm 25 \mathrm{pmol} / 1$ while maintaining euglycaemia. The infusion rate was designed to match the declines in plasma BCAA levels and leucine turnover observed during IGF-I infusion. The rates of glucose infusion necessary to maintain euglycaemia during IGF-I and insulin infusion were $4.9 \pm 1.0$ and $7.8 \pm 0.6 \mathrm{mg} \cdot \mathrm{kg}^{-1}$ . $\mathrm{min}^{-1}$, respectively. During insulin infusion total BCAA declined by $39 \%$ from $369 \pm 23$ to $226 \pm 20 \mu \mathrm{mol} / 1$, leucine flux declined by $16 \pm 2 \%$ from $1.90 \pm 0.05$ to $1.61 \pm 0.03 \mu \mathrm{mol} \cdot \mathrm{kg}^{-1} \cdot \mathrm{min}^{-1}$, and leucine oxidation declined by $19 \pm 2 \%$ from $0.32 \pm 0.02$ to $0.26 \pm 0.02 \mu \mathrm{mol} \cdot \mathrm{kg}^{-1} \cdot \mathrm{min}^{-1}$. On a molar basis IGF-I was $7.3 \%$ as potent as insulin in inhibiting proteolysis. These results demonstrate that in humans: (i) the hypoaminoacidaemic response to IGF-I can be entirely ascribed to the inhibition of proteolysis; (ii) qualitatively, the effects of IGF-I and insulin on plasma AA profile and protein metabolism are similar; (iii) quantitatively, IGF-I is 14-fold less potent than insulin in suppressing protein degradation. [Diabetologia (1995) 38: 732-738]

Key words Leucine, ketoisocaproate, insulin, IGF-I, protein metabolism.
Insulin-like growth factor (IGF-I) is a growth promoting peptide that shares considerable structural homology with insulin [1]. It induces cellular growth

Received: 18 May 1994 and in revised form: 29 December 1994

Corresponding author: Dr. R.A. DeFronzo, The University of Texas Health Science Center at San Antonio, Department of Medicine/Diabetes Division, 7703 Floyd Curl Drive, San Antonio, Texas 78284-7886, USA

Abbreviations: IGF-I, Insulin-like growth factor I; AA, aminoacid; BCAA, branched chain amino acids; KIC, alphaketoisocaproate; ELF, endogenous leucine flux; NOLD, non-oxidative leucine disposal. and differentiation [2], stimulates cellular glucose uptake and metabolism [3], and enhances renal sodium reabsorption, as well as extrarenal potassium and phosphate disposal [4]. All of these effects are qualitatively similar to the action of insulin. In vitro, IGFI also exerts a strong anabolic action on protein metabolism [5]. In vivo, IGF-I promotes a decline in plasma amino acid and serum urea nitrogen levels [6] and enhances nitrogen balance [7]. However, controversy still exists concerning the mechanisms of action of IGF-I on protein metabolism in vivo. Following low-dose IGF-I administration an inhibition of endogenous proteolysis and protein oxidation have 
not been uniformly observed $[6,8,9]$. In addition, in humans a comparison of the effects of IGF-I and insulin on parameters of protein metabolism, i.e. plasma aminoacid levels, protein degradation, protein synthesis, and protein oxidation, has not been described.

In the present study we compared doses of IGF-I and insulin which induced a similar decline in plasma branched chain amino acid (BCAA) concentration in order to compare: (i) their action on protein synthesis and protein degradation; (ii) the molar ratio of effectiveness of the two hormones.

\section{Subjects and methods}

Subjects. Eight healthy subjects ranging in age from 19 to 28 years participated in two studies which were performed in random order. They had no history of renal, metabolic or cardiovascular diseases, and routine screening tests, including blood chemistries and urinanalysis, were normal. There were four males and four females and all were within $20 \%$ of their ideal body weight based upon the midpoint for medium-frame individuals from the Metropolitan Life Insurance Tables, 1959. Their weight and height were $73 \pm 2 \mathrm{~kg}$ and $171 \pm 3 \mathrm{~cm}$, respectively. All the females had a negative serum pregnancy test prior to their participation. The purpose and potential risks of the study were explained to all subjects and their voluntary written consent was obtained before their participation. The study protocol was approved by the Institutional Review Board of the University of Texas Health Science Center.

Experimental protocol. All studies were performed at 08.00 hours after a 12 -h overnight fast. A polyethylene catheter was inserted into an antecubital vein for the infusion of all test substances. Blood samples were taken from a second catheter placed retrogradely into a wrist vein. The hand was kept in a heated box at $65^{\circ} \mathrm{C}$ to ensure arterialization of the venous blood. In each study protocol a primed-continuous infusion of $\left[1-{ }^{14} \mathrm{C}\right]$-leucine $(12 \mu \mathrm{Ci}$ prime followed by $0.16 \mu \mathrm{Ci} / \mathrm{min})$ was administered for $360 \mathrm{~min}$. A bolus of $\left[{ }^{14} \mathrm{C}\right]$ bicarbonate $(2.5 \mu \mathrm{Ci})$ was given at the start of the $\left[1-{ }^{14} \mathrm{C}\right]$ leucine. After $120 \mathrm{~min}$ of isotope equilibration, samples were drawn every 10-15 min from 120 to $180 \mathrm{~min}$ for leucine and alpha-ketoisocaproate (KIC) specific activities, and plasma insulin, IGF-I, amino acid, and ketoacid concentrations during both basal and hormone infusion periods. Continuous indirect calorimetry was carried out during the last $60 \mathrm{~min}$ of the basal and hormone infusion periods using a Deltatrac Metabolic Monitor, (Sensormedics, Anaheim, Calif., USA), as previously described [10]. Expired air samples were collected at $15-\mathrm{min}$ intervals and bubbled through a carbon dioxide-trapping solution (hyamine hydroxide/absolute ethanol/phenolphthalein, $3: 5: 1$ ). The solution was titrated to trap $1 \mathrm{mmol}$ of $\mathrm{CO}_{2}$ per $3 \mathrm{ml}$ of solution. The ${ }^{14} \mathrm{C}$ radioactivity was subsequently determined using a LS $5000 \mathrm{SE}$ scintillation counter (Beckman Instruments Corp., Fullerton, Calif., USA) and the expired ${ }^{14} \mathrm{CO}_{2}$ specific activity calculated. Total ${ }^{14} \mathrm{CO}_{2}$ expired per min was determined by multiplying the ${ }^{14} \mathrm{CO}_{2}$ specific activity by the total $\mathrm{CO}_{2}$ production rate obtained from indirect calorimetry. At the end of the 180 -min basal period all eight subjects received in random order one of the following study protocols: Study I: Euglycaemic IGF-I clamp. After the 180-min equilibration period, a continuous infusion of IGF-I (Genentech, San Francisco, Calif., USA) was administered at the rate of 52 $\mathrm{pmol} \cdot \mathrm{kg}^{-1} \cdot \min ^{-1}$ for $180 \mathrm{~min}$ to achieve a steady-state increase in plasma free IGF-I concentration of about $7.3 \mathrm{nmol} / 1$. Study II: Euglycaemic insulin clamp. Each subject who had received IGF-I was restudied on a second occasion within 23 weeks with a euglycaemic hyperinsulinaemic clamp [11]. After a 180 -min equilibration period for $\left[1-{ }^{14} \mathrm{C}\right]$ leucine, a continuous infusion of crystalline porcine insulin (Eli Lilly and Co., Indianapolis, Ind., USA) was administered at a rate of 6.2 pmol $\cdot \mathrm{kg}^{-1} \cdot \mathrm{min}^{-1}$ for $180 \mathrm{~min}$ to achieve and maintain an increase in plasma insulin concentration of $530 \pm 25 \mathrm{pmol} / 1$. The insulin infusion rate was determined empirically on the basis of previous experience [12] to achieve a decline in plasma BCAA levels comparable to those observed during IGF-I infusion. In both the insulin and IGF-I studies, the plasma glucose concentration was maintained constant within $10 \%$ of the basal level by determination of the plasma glucose concentration at 5-min intervals and periodic adjustment of an exogenous glucose infusion as previously described [11]. IGF-I and insulin solutions were prepared by adding $2 \mathrm{ml}$ of the subject's own blood to normal saline in order to prevent hormone binding to plastic material.

Analytical determinations. Plasma amino acid concentrations were determined using an amino acid analyser (System 6300, Beckman Corp.). To precipitate plasma proteins, $2 \mathrm{ml}$ of $10 \%$ sulphosalicylic acid was added to $2 \mathrm{ml}$ of plasma and a $1-\mathrm{ml}$ aliquot of the supernatant was analysed in duplicate. To determine the plasma leucine specific activity, $1 \mathrm{ml}$ of the remaining supernatant was placed in duplicate on a cation exchange resin column (Dowex 50 G; Bio-Rad Laboratory, Richmond, Calif., USA) and the free amino acid fraction was eluted with $4 \mathrm{~mol} / \mathrm{l}$ of $\mathrm{NH}_{4} \mathrm{OH}$, evaporated to dryness, and reconstituted in water [13]. Hydrofluoric scintillation fluid $(10 \mathrm{ml})$ was added to each vial and ${ }^{14} \mathrm{C}$ radioactivity was measured in a scintillation counter. The recovery of $\left[{ }^{14} \mathrm{C}\right]$ leucine added to plasma was $97 \pm 2 \%$. More than $96 \%$ of the radioactivity collected in the amino acid fraction was present in the leucine peak after separation by ion exchange chromatography. The interassay and intra-assay coefficients of variation for determination of plasma leucine specific activity were $4 \pm 2$ and $5 \pm 3 \%$ respectively. Plasma KIC concentration was determined using a modification of the method previously described by Nissen et al. [14]. Plasma $(1 \mathrm{ml})$ was placed in duplicate on a Dowex $50 \mathrm{G}$ cation exchange resin column (Bio-Rad) and the free alphaketoacid fraction was eluted with $4 \mathrm{ml}$ of $0.01 \mathrm{~mol} / 1 \mathrm{HCl}$ in 50 $\mathrm{ml}$ culture tubes. A quantity of $35 \mathrm{ml}$ of methylene chloride was added and after shaking vigorously for 3 min the tube was centrifuged for $5 \mathrm{~min}$ at $2000 \mathrm{rev} / \mathrm{min}$ to extract the free alpha-ketoacid fraction from plasma. After decanting the supernatant the alpha-ketoacid was extracted in $350 \mathrm{ul}$ of $0.2 \mathrm{~mol} / 1$ $\mathrm{NaH}_{2} \mathrm{PO}_{4}$ at $\mathrm{pH}$ 7.0. After a brief centrifugation, $200 \mu \mathrm{l}$ of the supernatant was injected into an HPLC system. The system utilizes a C18-reverse phase column $(0.3 \times 30 \mathrm{~cm}$, Waters Nova-Pak, Milford, Mass., USA) which was eluted with $2 \%$ acetonitrile in $0.1 \mathrm{~mol} / 1 \mathrm{NaH}_{2} \mathrm{PO}_{4}$ buffer $(\mathrm{pH} 7.4$ ) at a rate of $1.4 \mathrm{ml} / \mathrm{min}$. Absorbance of $\mathrm{KIC}$ was monitored at $206 \mathrm{~nm}$. The recovery of the procedure was $68 \pm 4 \%$. The interassay and intra-assay coefficients of variation for the determination of plasma KIC specific activity were $5 \pm 2$ and $5 \pm 3 \%$, respectively. Plasma insulin and glucagon concentrations were determined using a double antibody radioimmunoassay technique (Diagnostic Products Corp., Los Angeles, Calif., USA). The total plasma IGF-I concentration was determined by radioimmunoassay after acid ethanol extraction, and plasma free IGF-I was determined by radioimmunoassay after separation from binding protein-complexed IGF-I, using a size exclusion HPLC system [15]. Plasma glucose concentration was deter- 
Table 1. Plasma insulin, glucagon, total IGF-I and free IGF-I concentrations at baseline and during the last 60 min of IGF-I and insulin infusion studies

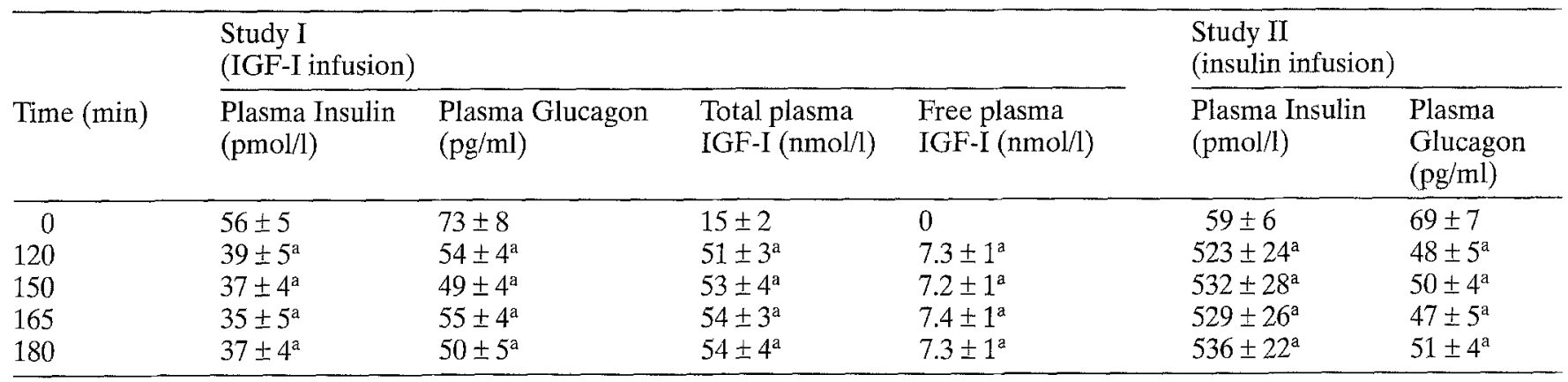

Mean \pm SEM.

${ }^{\mathrm{a}} p<0.01$ vs basal

mined by the glucose oxidase method using a Beckman Glucose Analyzer (Beckman Instruments).

Calculations. Plasma leucine kinetics were determined using steady-state isotope dilution equations and the reciprocal pool model, which utilizes the specific activity of ${ }^{14} \mathrm{C}$ alpha$\mathrm{KIC}$, the transamination product of leucine and the preferred indicator of intracellular leucine specific activity [16]. Leucine oxidation was estimated by dividing the rate of expired ${ }^{14} \mathrm{CO}_{2}$ by the plasma specific activity of alpha-KIC, the immediate precursor for oxidative decarboxylation of leucine. Because of incomplete recovery of labelled $\left[{ }^{14} \mathrm{C}\right]$ carbon dioxide from the bicarbonate pool [17], the rate of ${ }^{14} \mathrm{CO}_{2}$ excretion in expired air was corrected upward by $20 \%$. Since under the present experimental conditions the only input of leucine into the body is from protein stores, the endogenous leucine flux (ELF) provides an index of total body proteolysis. Non-oxidative leucine disposal (NOLD), an estimate of whole body protein synthesis, was calculated by subtracting the rate of leucine oxidation from the rate of ELF. The difference between NOLD (an index of protein synthesis) and ELF (an index of proteolysis) represents the net leucine balance or the net flux of leucine into and out of protein [12].

\section{Statistical analysis}

All values are expressed as the mean \pm SEM. The paired $t$-test was used to detect statistically significant changes in ELF, NOLD, and leucine oxidation from baseline. Differences between IGF-I and insulin were determined using one-way analysis of variance (ANOVA) with repeat measures. A $p$-value less than 0.05 was considered to represent a statistically significant difference.

\section{Results}

Plasma IGF-I, insulin and glucagon concentrations (Table 1). Total and free plasma IGF-I levels were determined only in the IGF-I infusion study. The basal plasma total IGF-I concentration was $15 \pm 2 \mathrm{nmol} / 1$, and the basal free IGF-I concentration was undetectable. Following IGF-I infusion (Study I), plasma total and free IGF-I levels achieved a steady-state plateau during the last hour of hormone infusion and aver- aged $53 \pm 4$ and $7.3 \mathrm{nmol} / \mathrm{l}$, respectively. During IGFI infusion, plasma insulin declined from $56 \pm 5$ to $37 \pm 5 \mathrm{pmol} / \mathrm{l}(p<0.01)$. During the euglycaemic insulin clamp (Study II), the basal plasma insulin (59 \pm 6 $\mathrm{pmol} / \mathrm{l})$ increased to a plateau level of $530 \pm 2 \mathrm{pmol} / \mathrm{l}$ $(p<0.01)$.

Basal plasma glucagon levels were similar in the two studies $(71 \pm 8 \mathrm{pg} / \mathrm{ml})$ and declined to $52 \pm 4$ and $49 \pm 5 \mathrm{pg} / \mathrm{ml}$ (both $p<0.01 \mathrm{vs}$ basal) following IGF-I and insulin infusion, respectively.

Amino acid metabolism (Table 2, Fig. 1). In the basal state total plasma amino acid concentrations were similar in the two studies and averaged $1975 \pm 169 \mu \mathrm{mol} / \mathrm{l}$. During the last hour of IGF-I (Study I) and insulin (Study II) infusion, the total plasma amino acid concentration reached plateau values of $1368 \pm 120$ and $1620 \pm 132 \mu \mathrm{mol} / \mathrm{l}$, respectively (both $p<0.01$ vs basal; $p<0.05$ for insulin vs IGF-I). The plasma BCAA levels decreased similarly during IGF-I ( $390 \pm 21$ to $256 \pm 13 \mu \mathrm{mol} / \mathrm{l} ; 35 \pm 3 \%$ ) and insulin ( $369 \pm 23$ to $226 \pm 20 \mu \mathrm{mol} / / ; 39 \pm 2 \%$ ) infusion. The decline in basal $(1212 \pm 100 \mu \mathrm{mol} / \mathrm{l})$ gluconeogenic amino acid concentration was greater with IGF-I $(848 \pm 80 \mu \mathrm{mol} / 1)$ than with insulin $(1049 \pm$ $85 \mu \mathrm{mol} / 1$ ) (both $p<0.01$ vs basal and $p<0.05$ for insulin vs IGF-I).

Basal endogenous leucine flux, an estimate of protein breakdown, was similar in the IGF-I and insulin infusion studies and averaged $1.88 \pm 0.05$ and $1.90 \pm 0.05 \mu \mathrm{mol} \cdot \mathrm{kg}^{-1} \cdot \mathrm{min}^{-1}$, respectively. Following IGF-I and insulin infusion, the decline in leucine turnover was similar in the two studies and aver- aged $17 \pm 2 \% \quad(1.57 \pm 0.04$ in study $I$ and $1.61 \pm$ $0.04 \mu \mathrm{mol} \cdot \mathrm{kg}^{-1} \cdot \mathrm{min}^{-1}$ in study II) (both $p<0.01 \mathrm{vs}$ basal and $p=\mathrm{NS}$ for study I vs study II). Basal leucine oxidation averaged $0.31 \pm 0.02$ in study $I$ and $0.32 \pm 0.02 \mu \mathrm{mol} \cdot \mathrm{kg}^{-1} \cdot \mathrm{min}^{-1}$ in study II. Following IGF-I and insulin infusion, leucine oxidation declined by $17 \pm 2 \%$ to $0.26 \pm 0.02 \mu \mathrm{mol} \cdot \mathrm{kg}^{-1} \cdot \mathrm{min}^{-1}$ and by $19 \pm 2 \%$ to $0.26 \pm 0.02 \mu \mathrm{mol} \cdot \mathrm{kg}^{-1} \cdot \mathrm{min}^{-1}$ in studies I and II, respectively (both $p<0.01$ vs basal). Non-oxi- 
Table 2. Plasma amino acid concentrations ( $\mu \mathrm{mol} / 1)$ at baseline and during the last $60 \mathrm{~min}$ of IGF-I and insulin infusion

\begin{tabular}{|c|c|c|c|c|}
\hline & \multicolumn{2}{|l|}{ Study I } & \multicolumn{2}{|l|}{ Study II } \\
\hline & Basal & IGF-I & Basal & Insulin \\
\hline \multicolumn{5}{|c|}{ Amino acid $(\mu \mathrm{mol} / \mathrm{l})$} \\
\hline Aspartate & $11 \pm 1$ & $9 \pm 1^{a}$ & $9 \pm 0.7$ & $7 \pm 0.7^{\mathrm{a}}$ \\
\hline Threonine & $123 \pm 12$ & $75 \pm 8^{b}$ & $116 \pm 9$ & $103 \pm 13^{a}$ \\
\hline Serine & $99 \pm 5$ & $72 \pm 5^{\mathrm{a}}$ & $102 \pm 8$ & $77 \pm 6^{a}$ \\
\hline Glutamine & $537 \pm 50$ & $362 \pm 20^{b}$ & $538 \pm 25$ & $445 \pm 31^{b}$ \\
\hline Glycine & $203 \pm 33$ & $155 \pm 18^{a}$ & $215 \pm 11$ & $191 \pm 13$ \\
\hline Alanine & $250 \pm 59$ & $184 \pm 32^{a}$ & $241 \pm 23$ & $233 \pm 16$ \\
\hline Valine & $213 \pm 12$ & $157 \pm 8^{b}$ & $185 \pm 13$ & $126 \pm 13^{b}$ \\
\hline Cysteine & $53 \pm 2$ & $45 \pm 2$ & $65 \pm 3$ & $60 \pm 2$ \\
\hline Methionine & $35 \pm 1$ & $25 \pm 1^{\mathrm{a}}$ & $40 \pm 3$ & $34 \pm 3^{a}$ \\
\hline Isoleucine & $59 \pm 3$ & $29 \pm 1^{b}$ & $66 \pm 4$ & $37 \pm 3^{b}$ \\
\hline Leucine & $118 \pm 5$ & $69 \pm 4^{\mathrm{a}}$ & $118 \pm 7$ & $65 \pm 4^{b}$ \\
\hline Tyrosine & $45 \pm 2$ & $29 \pm 2^{a}$ & $55 \pm 10$ & $32 \pm 3^{b}$ \\
\hline $\begin{array}{l}\text { Phenylala- } \\
\text { nine }\end{array}$ & $48 \pm 2$ & $34 \pm 4^{a}$ & $49 \pm 5$ & $38 \pm 7^{\mathrm{a}}$ \\
\hline Lysine & $179 \pm 9$ & $120 \pm 4^{\mathrm{a}}$ & $176 \pm 20^{\mathrm{a}}$ & $174 \pm 18$ \\
\hline $\begin{array}{l}\text { Total } \\
\text { BCAA }\end{array}$ & $390 \pm 21$ & $256 \pm 13^{b}$ & $369 \pm 23$ & $226 \pm 20^{\mathrm{b}}$ \\
\hline Total AA & $1975 \pm 198$ & $1368 \pm 120^{b}$ & $1974 \pm 140$ & $1620 \pm 132^{b}$ \\
\hline
\end{tabular}

Mean \pm SEM.

${ }^{\mathrm{a}} p<0.05 ;{ }^{\mathrm{b}} p<0.01$ vs basal

dative leucine disposal, an index of protein synthesis, declined similarly following IGF-I (from $1.57 \pm 0.04$ to $1.31 \pm 0.04 \mu \mathrm{mol} \cdot \mathrm{kg}^{-1} \cdot \mathrm{min}^{-1}$; by $16 \pm 1 \%$ ) and insulin (from $1.58 \pm 0.07$ to $1.35 \pm 0.05 \mu \mathrm{mol} \cdot \mathrm{kg}^{-1}$. $\min ^{-1}$; by $15 \pm 1 \%$ ) infusion (both $p<0.01$ vs basal). The net leucine balance in the postabsorptive state was similar in study I $\left(-0.30 \pm 0.02 \mu \mathrm{mol} \cdot \mathrm{kg}^{-1} \cdot \mathrm{min}^{-1}\right)$ and study II $\left(-0.31 \pm 0.02 \mu \mathrm{mol} \cdot \mathrm{kg}^{-1} \cdot \mathrm{min}^{-1}\right)$ and became less negative following both IGF-I $(-0.26 \pm 0.02)$ and insulin $(-0.27 \pm 0.02)$ infusion ( $p=$ NS IGF-I vs insulin; both $p<0.01$ vs basal).
Plasma glucose concentration and glucose infusion rate. Basal plasma glucose levels were similar in the two study protocols and averaged $4.96 \pm 0.1 \mathrm{mmol} / 1$ and were maintained at $4.90 \pm 0.2 \mathrm{mmol} / \mathrm{l}$ and $5.01 \pm 0.2 \mathrm{mmol} / \mathrm{l}$ (coefficient of variation $<5 \%$ in all studies) during IGF-I and insulin infusion, respectively.

The rates of exogenous glucose infusion required to maintain euglycaemia during the last $60 \mathrm{~min}$ of IGF-I and insulin infusion were $4.9 \pm 1.0$ and $7.8 \pm 0.6 \mathrm{mg} \cdot \mathrm{kg}^{-1} \cdot \mathrm{min}^{-1}$, respectively $(p<0.01)$.

\section{Discussion}

The present results demonstrate that IGF-I infusion induces a significant decline in total plasma amino acid levels in fasting humans, and this can be ascribed entirely to an inhibition of endogenous proteolysis. This hypoaminoacidaemic effect of IGF-I is in agreement with results reported by Boulware et al. [18]. Under the present experimental conditions, enhanced amino acid disposal does not contribute to the hypoaminoacidaemic effect of IGF-I since both protein oxidation and protein synthesis declined significantly. Because the decline in proteolysis exceeded the fall in protein synthesis, the net leucine balance became less negative, resulting in a net anabolic effect of IGF-I. From the present findings, it can be concluded that the primary anabolic action of IGF-I is mediated by its ability to inhibit proteolysis. From the qualitative standpoint, therefore, the effects of IGF-I on protein metabolism are similar to those of insulin [12]. From the quantitative standpoint, however, IGF-I is less potent than insulin. As calculated from the plasma free IGF-I concentrations, it is on a molar basis only $7 \%$ as effective as insulin in inhibiting proteolysis under the present experimental conditions. From the data of Turkalj et al. [8], it can be assumed that the dose of IGF-I em-

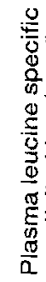
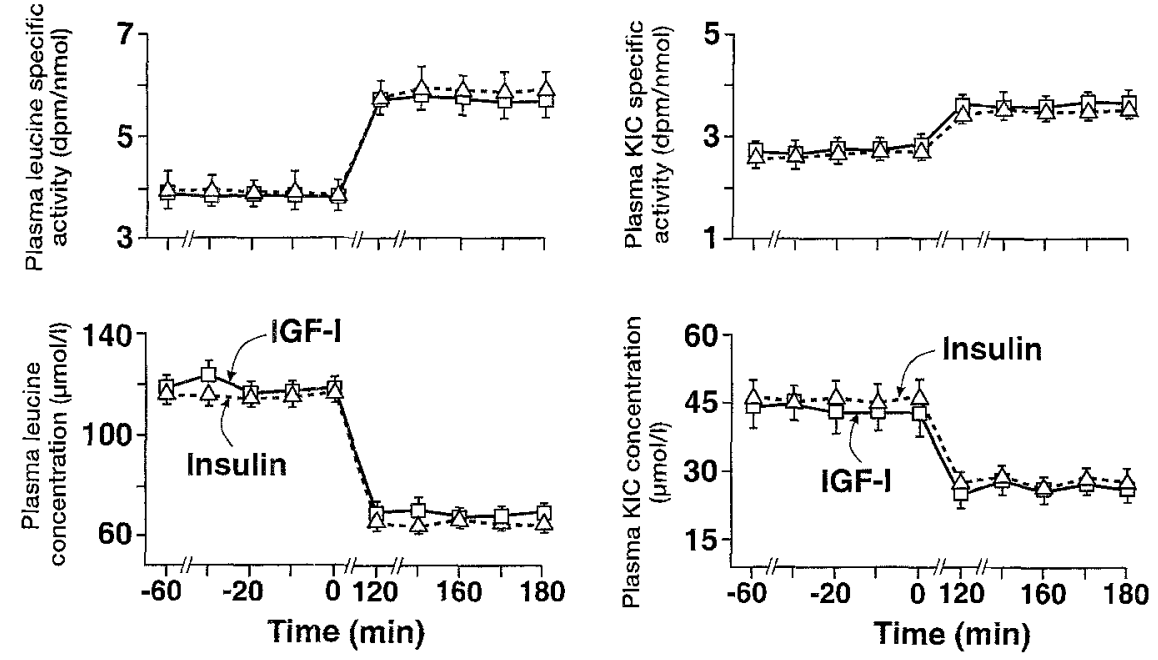

Fig. 1. Time-related change in plasma leucine and KIC concentrations and plasma leucine and $\mathrm{KIC}$-specific activities in the basal state and during IGF-I and insulin infusion 

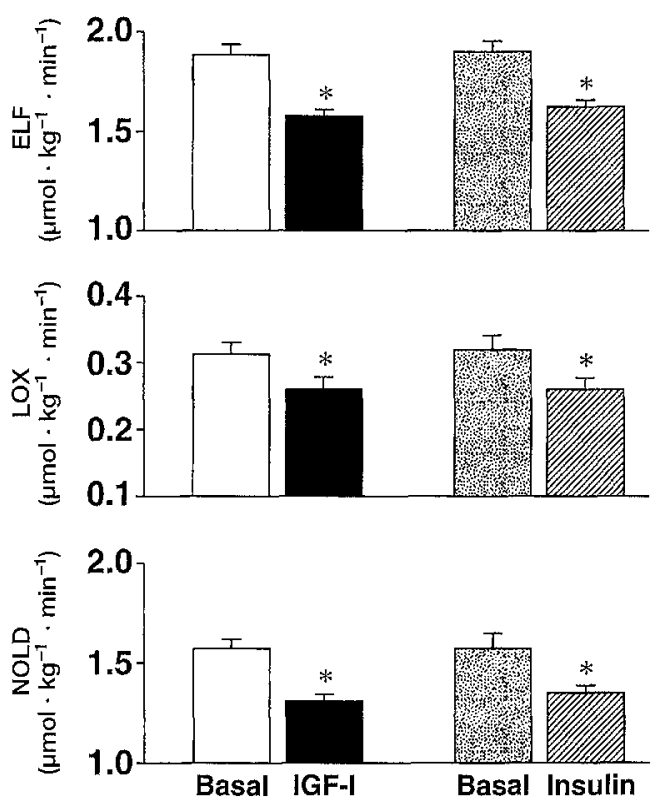

Fig. 2. Endogenous leucine flux (ELF), leucine oxidation (LOX), and non-oxidative leucine disposal (NOLD) in the basal state and during IGF-I and insulin infusion $(* p<0.01 \mathrm{vs}$ basal)

ployed in the present study induced a maximal inhibition of endogenous proteolysis. Whether the same potency ratio also will be observed with lower IGF-I levels remains to be determined.

Previous studies in humans have suggested that IGF-I exerts a protein-sparing effect. Following administration of high doses of IGF-I, Guler et al. [19] demonstrated an acute decline in blood urea nitrogen in healthy subjects, and similar findings have been reported by Clemmons et al. [7] in healthy subjects following moderate caloric restriction. In this later study [7] IGF-I was also shown to induce a more positive nitrogen balance. Studies in animals employing various tracer methodologies, including 3-methylhistidine and ${ }^{14} \mathrm{C}$-leucine, also have provided evidence that the anabolic action of IGF-I is mediated by the inhibition of endogenous proteolysis [20-22]. A stimulation of protein synthesis by IGF-I has been observed in growing lambs [21] and in rats subjected to dietary nitrogen restriction [22], but not in rats maintained on a free dietary intake [20]. In normal humans, most $[6,8,23]$ but not all studies [9] using the leucine turnover technique to examine protein metabolism, have reported an inhibitory effect on proteolysis. In particular, studies which have examined the effect of small increments in the plasma IGF-I concentration have not uniformly observed a decrease in protein degradation $[8,9]$. Similarly, an inhibition of leucine oxidation has been reported consistently only with high doses of IGF-I $[8,23]$. With low circulating levels of IGF-I, either a moderate decline $[8]$ or no change $[6,9]$ in leucine oxidation has been reported. Our findings are in agree- ment with the data of Elahi et al. [6] and Turkalj et al. [8] and support the concept that IGF-I primarily exerts its anabolic effect by inhibiting proteolysis.

We also observed a consistent decline in leucine oxidation. The percent reduction in leucine oxidation observed following IGF-I administration (17\%) was similar to the decline in proteolysis $(17 \%)$. A similar percent decline $(19 \%)$ in leucine oxidation was observed following insulin administration. These results suggest that, as previously shown for insulin [12], the decline in protein oxidation most likely results from the inhibition of proteolysis and the attendant decline in substrate availability. In contrast to the BCAA, plasma gluconeogenic amino acid levels declined more following IGF-I than insulin infusion. Since endogenous proteolysis was inhibited to a similar extent, it is possible that the lower gluconeogenic amino acid levels are the result of their greater hepatic utilization during IGF-I infusion. As suggested by Jacob et al. [20], this could be explained if hepatic gluconeogenesis was less sensitive to IGF-I than insulin. This hypothesis is consistent with recent reports that IGF-I causes a lesser inhibition of hepatic glucose production and a greater stimulation of hepatic glycogen synthesis than insulin $[20,23]$.

The concentration of plasma free IGF-I, rather than protein bound IGF-I appears to be responsible for IGF-I's insulin-like effects [24]. It has been suggested that circulating IGF-I binding proteins can alter the action of IGF-I. In the present study no measurements of IGF-I binding proteins were performed. Therefore, no direct conclusion about their role in regulating the action of IGF-I on amino acid/ protein metabolism can be reached. However, Mauras et al. [9] failed to observe any significant rise in IGF-I binding proteins following IGF-I infusion. This mitigates against a role for changes in binding proteins in the modulation of the acute effects of IGF-I on protein metabolism. This is also supported by recent data on the truncated forms of IGF-I that show a lower affinity for binding proteins and higher potency than the genuine IGF-I form [22]. It also has been suggested that the tissue level of IGF-I may provide a more accurate reflection of its biological effectiveness. Unfortunately, such measurements are difficult to perform in man. Therefore, we believe that, at the present time, the plasma free IGF-I concentration affords the best comparison of the quantitative effects of IGF-I and insulin on protein metabolism. Previous studies that have compared the biologic potency of IGF-I and insulin on glucose disposal have reported values ranging from 1 to $8 \%[6,19,20,25]$. With respect to protein metabolism, no similar comparisons between IGF-I and insulin have been described. To address this question, we chose doses of IGF-I and insulin which produced similar effects on BCAA levels and leucine metabolism so that we could directly compare the molar ratio between the 
plasma free IGF-I and insulin concentrations on protein metabolism. On a molar basis the plasma concentration of free IGF-I required to elicit the same effect as insulin (Table 1) on protein metabolism was 14 to 1 . Thus, on a molar basis IGF-I was only $7 \%$ as potent as insulin. However, this calculation is based upon the assumption that all of the effects of IGF-I are mediated via the IGF-I receptor. In vitro studies [26] have shown that IGF-I binds to the insulin receptor but with an affinity which is $1 / 50-1 / 100$ that of insulin. Therefore, if the action of IGF-I on protein metabolism was entirely mediated by the insulin receptor, a molar potency ratio of 1 to $50-100$ would have been expected. The observed molar ratio in the present study of 1 to 14 suggests that the effects of IGFI on protein metabolism in vivo are primarily mediated by its own receptor. Alternatively, one could postulate the existence of hybrid IGF-I/insulin receptors, or a synergistic post-receptor action of the two hormones.

The rate of exogenous glucose infusion required to maintain euglycaemia was $60 \%$ greater with insulin than with IGF-I. Even if one takes into account the less effective inhibition of hepatic glucose production by IGF-I compared to insulin [23], our results suggest a greater sensitivity to IGF-I on protein than on glucose metabolism. These findings are consistent with recently published data in humans [23] and in lambs [21]. Since exogenous IGF-I administration inhibited insulin secretion and circulating insulin levels declined from 56 to $37 \mathrm{pmol} / \mathrm{l}$, the metabolic action of IGF-I may have been slightly underestimated by the attendant hypoinsulinaemia.

In conclusion, the present results indicate that the effects of IGF-I and insulin on protein metabolism are qualitatively similar. On a molar basis, however, IGF-I is only $7 \%$ as potent as insulin in inhibiting protein degradation and oxidation. The differential effect of IGF-I on protein and glucose metabolism suggests that IGF-I may be preferable to insulin in highly catabolic states when one wants to avoid concomitant hypoglycaemia.

Acknowledgements. The authors wish to thank Ms. L. Olivarri and Ms. R. Ramos-Echandi for assistance in the preparation of the manuscript. IGF-I was provided by Genentech, San Francisco, Calif., USA. This work was supported in part by General Clinical Research Center grant M01-RR-01346, a VA Merit Award, and funds from the VA Medical Research Center.

\section{References}

1. Rinderknecht E, Humbel RE (1978) The amino acid sequence of insulin-like growth factor I and its structural homology with proinsulin. J Biol Chem 253: 2769-2776

2. Shoenle E, Zapf J, Humbel RE, Froesh ER (1982) Insulinlike growth factor I stimulates growth in hypophysectomized rats. Nature 296:252-253
3. Sinha MK, Buchanan C, Leggett N et al. (1989) Mechanism of IGF-I stimulated glucose transport in human adipocytes: demonstration of specific IGF-I receptors not involved in stimulation of glucose transport. Diabetes 38: 1217-1225

4. Hirschberg R, Brunori G, Kopple JD Guler HP (1993) Effects of insulin-like growth factor I on renal function in normal men. Kidney Int 43: 387-397

5. Poggi C, LeMarchand-Brustel Y, Zapf J, Froesh ER, Freychet P (1979) Effects and binding of insulin-like growth factor I in the isolated soleus muscle of lean and obese mice: comparison with insulin. Endocrinology 105: 723730

6. Elahi D, McAloon-Dyke M, Fukagawa NK et al. (1993) Effects of recombinant human IGF-I on glucose and leucine kinetics in men. Am J Physiol 265 (Endocrinol Metab 28): E831-E838

7. Clemmons DR, Smith-Banks A, Underwood LE (1992) Reversal of diet-induced catabolism by infusion of recombinant insulin-like growth factor-I in humans. J Clin Endocrinol Metab 75: 234-238

8. Turkalj I, Keller U, Ninnis R, Vosmeer S, Stauffacher W (1992) Effect of increasing doses of recombinant human insulin-like growth factor I on glucose, lipid and leucine metabolism in man. J Clin Endocrinol Metab 75: 1186-1191

9. Mauras N, Horber FF, Hymond MW (1992) Low dose recombinant human insulin-like growth factor-I fails to affect protein anabolism but inhibits islet cell secretion in humans. J Clin Endocrinol Metab 75: 1192-1197

10. Simonson DC, DeFronzo RA (1990) Indirect calorimetry: methodological and interpretative problems Am J Physiol 258 (Endocrinol Metab 21): E399-E412

11. DeFronzo RA, Tobin JD, Andres R (1979) Glucose clamp technique: a method for quantifying insulin secretion and resistance. Am J Physiol 237: E214-E223

12. Castellino P, Luzi L, Simonson DC, Haymond M, DeFronzo RA (1987) Effect of insulin and plasma amino acid concentrations on leucine metabolism in man. J Clin Invest 80: $1784-1793$

13. O'Keefe SJD, Moldawer LL, Young VR, Blackburn GL (1981) The influence of intravenous nutrition on protein dynamics following surgery. Metab 30: 1150-1158

14. Nissen SL, Van Huisen C, Haymond MW (1982) Measurement of branched chain amino acids and branched chained alpha-keto acids in plasma by high-performance liquid chromatography. J Chromatogr 232: 170-175

15. Lieberman SA, Bukar J, Chen SA et al. (1992) Effects of recombinant human insulin-like growth factor I (th IGF-1. on total and free IGF-I concentrations, IGF binding proteins, and glycemic response in humans. $J$ Clin Endocrinol Metab 75: 30-36

16. Schwenk WF, Beaufrere B, Haymond MW (1985) Use of reciprocal pool specific activities to model leucine metabolism in humans. Am J Physiol 249 (Endocrinol Metab 12): E646-E650

17. Issekutz B, Paul P, Miller HI, Bortz WM (1968) Oxidation of FFA in lean and obese humans. Metab 17: 62-73

18. Boulware SD, Tamborlane WV, Matthews LS, Sherwin RS (1992) Diverse effects of insulin-like growth factor I on glucose, lipid, and amino acid metabolism. Am J Physiol 261 (Endocrinol Metab 25): E130-E133

19. Guler HP, Schmid C, Zapf J, Froesh ER (1989) Effects of recombinant insulin-like growth factor $I$ on insulin secretion and renal function in normal human subjects. Proc Natl Acad Sci 86: 2868-2872

20. Jacob R, Barrett E, Plewe G, Fagin KD, Sherwin RS (1989) Acute effects of insulin-like growth factor I on glucose and 
amino acid metabolism in awake fasted rat. $J$ Clin Invest 83: $1717-1723$

21. Douglas RG, Gluckman PD, Ball K, Breier B, Shaw JHF (1991) The effects of infusion of insulin-like growth factor (IGF) I, IGF-II, and insulin on glucose and protein metabolism in fasted lambs. J Clin Invest 88: 614-622

22. Tomas FM, Knowles SE, Owens PC et al. (1992) Insulinlike growth factor I and especially IGF-I variants are anabolic in dexamethasone-treated rats. Biochem J 282: 91-97

23. Laager R, Ninnis R, Keller U (1993) Comparison of the effects of recombinant human insulin-like growth factor-I and insulin on glucose and leucine kinetics in humans. J Clin Invest 92: 1903-1909

24. Guler HP, Zapf J, Schmid C, Froesch ER (1989) Insulin-like growth factors I and II in healthy man. Estimation of halflives and production rates. Acta Endocrinol 121: 753-758

25. Guler HP, Zapf J, Froesch ER (1987) Short-term metabolic effects of recombinant human insulin-like growth factor I in healthy adults. N Engl J Med 317: 137-140

26. Czech MP (1982) Structural and functional homologies in the receptors for insulin and insulin-like growth factors. Cell 31: $8-10$ 